\title{
Moral Distress in Family Health Strategy: experiences expressed by daily life*
}

\author{
Sofrimento Moral na Estratégia de Saúde da Família: vivências desveladas no cotidiano \\ Sufrimiento Moral en la Estrategia Salud de la Familia : las \\ experiencias expresan en la vida cotidiana
}

Cecília Maria Lima Cardosoํㅜ, Maria Odete Pereira², Danielle de Araújo Moreira ${ }^{3}$, Hanna Beatriz Bacelar Tibães ${ }^{4}$, Flávia Regina Souza Ramos ${ }^{5}$, Maria José Menezes Brito

\footnotetext{
* Experience of Moral Distress in the Family Health Strategy: professionals' vision. 2015, School of Nursing, University of Minas Gerais.

${ }^{1}$ Centro Universitário de Sete Lagoas -

UNIFEMM, Faculdade Ciências da Vida, Sete Lagoas, MG, Brazil.

2,3,4,6 Universidade Federal de Minas Gerais, Belo Horizonte, MG, Brazil.

${ }^{5}$ Universidade Federal de Santa

Catarina, Florianópolis, SC, Brazil.
}

\begin{abstract}
Objective: Understanding the Moral Suffering experiences expressed in the daily life of the Family Health Strategy.

Method: This is a case study with a qualitative approach, conducted between August and October 2014 in a municipality of Minas Gerais. The sample was represented by 28 professionals of family health teams. Data were collected through interviews with semi-structured questionnaires, observation, projective technique and submitted to thematic content analysis.

Results: The results indicate that routine issues of the health care system lead professionals to experience a challenging practice in dealing with daily situations that contradict their ethical precepts and can compromise the quality of work, becoming triggers of Moral Distress.

Conclusion: Social vulnerabilities such as domestic violence, poor socioeconomic conditions and organizational weaknesses of the health system were the main triggers of Moral Distress. Therefore, it is necessary to amplify this reflection by workers of the Family Health Strategy, aiming to encourage the minimization of suffering experiences, considering their ethical values.
\end{abstract}

\section{DESCRIPTORS}

Family Health Strategy; Ethics; Moral damage.
Correspondence Addressed to:

Cecília Maria Lima Cardoso

Avenida Marechal Castelo Branco, n 2765 , Bairro Santo Antônio

CEP 35701242, Sete Lagoas, MG, Brazil

cecilia.lima@unifemm.edu.br
Received: 26/03/2015

Approved: 14/11/2015 


\section{INTRODUCTION}

Primary Health Care (PHC) is generally the first contact of service users in relation to treatment plans based on rapport and continuity of care. This health care point is characterized by the development of highly complex clinical activities and longitudinal actions, which aim to ensure comprehensive care ${ }^{(1)}$.

In Brazil, PHC is organized by the Family Health Strategy (ESF), which aims to produce a service based on care and management models that are geared to meet the needs of service users, with an emphasis on health promotion and the prevention of illness. Consequently, it is based on family-centered health care that considers the environment in which people live and the space in which relationships are constructed ${ }^{(2)}$.

The ESF is guided by four key attributes: access to services at first contact; longitudinality; comprehensiveness; and coordination of care. These factors are recognized as the structural axes of the health care process and they are associated with the quality, effectiveness and efficiency of its services ${ }^{(2-3)}$

Through these assumptions, the actions of the ESF are intended to be conducted in a coordinated manner in conjunction with the services provided by the Health Care Network in order to respond to demands for service in an integrated manner. However, this requires efforts on the part of teams in order to act in a planned fashion and in accordance with the determinants of health to provide better living conditions for individuals, families and communities ${ }^{(4)}$.

The ESF has contributed towards the reorganization of the health care model through the adoption of new modes of behavior by both professionals and service users ${ }^{(5)}$. However, professionals often deal with situations that limit and hinder the effectiveness of the principles of PHC and this can result in members of health teams suffering from moral distress (MD).

Moral distress can be understood as pain or distress that affects the mind, body or interpersonal relationships in the workplace, in response to a situation in which a professional recognizes their moral responsibility in a given situation and has to make a judgment about the right conduct to be taken. However, the professional is unable to put that decision into practice due to service constraints, thereby provoking $\mathrm{MD}^{(6)}$.

The aspects that trigger MD are associated with difficulties in daily work, such as service organization and organizational policies, which influence the ability to exercise power, and can result in low levels of professional autonomy, restrictions on time and resources, and high levels of responsibility ${ }^{(7)}$.

Health workers develop MD when they have to make difficult choices between following the rules and following their conscience. Consequently, MD triggers traditional symptoms of negative stress that occur due to situations involving ethical dimensions, in which the professional feels that they are unable to guarantee all their personal interests and values ${ }^{(8)}$.
MD can be also described as a gap between the beliefs of an individual and their actions, which results in psychological distress caused by painful feelings ${ }^{(9-10)}$. Thus, MD has implications for the lives of health workers in personal terms, which are represented by emotional and physical symptoms, and also in professional terms, which are related to job satisfaction and even the abandonment of the profession ${ }^{(11)}$

It is worth noting the lack of studies on this topic, especially in terms of $\mathrm{PHC}$, which demonstrates the need for studies that explore the experiences of MD in the everyday life of professionals working within the Family Health Strategy in greater depth and from an interdisciplinary perspective.

Given the above, the objective of this study was to understand the experiences of moral distress expressed in the daily lives of people working within the Family Health Strategy

\section{METHODS}

This study used a qualitative approach and the research method was that of a case study.

Qualitative research makes it possible to immerse oneself more deeply in relationships, processes and phenomena which correspond to the universe of meanings, feelings, beliefs, values, attitudes and aspirations ${ }^{(12)}$. Qualitative research aims to capture the different meanings of lived experiences; in this specific case aiding the understanding of individuals working in the context of the ESF.

Case studies consist of a research strategy that studies events within the context of real life; they are considered to be the most appropriate design for investigating contemporary cases, within their real context, where the boundary between these are not clearly defined ${ }^{(13)}$.

This study was conducted between August and October 2014 at four Family Health Teams in a municipality located in the interior of the state of Minas Gerais, Brazil. The following were used to collect data: observation; semi-structured interviews; and a projective technique using a cartoon entitled "Moral Distress". The strategy was developed by the following research centers: PRAXIS - work, citizenship, health and nursing - (PEN/UFSC) at the Nursing School of the Federal University of Santa Catarina; The Center for Studies and Research in Nursing/Health (NEPS) at the Nursing School of the Federal University of Rio Grande (FURG); and the Center for Research in Nursing Administration (NUPAE) at the Nursing School of the Federal University of Minas Gerais (UFMG) (Figure 1).

A cartoon was presented to the research participants which illustrated a day's work in the life of health professionals. The story was intended to introduce the concept of MD in a playful manner that was based on experiences. After the presentation, the research participants were requested to answer the following main question: "Describe a situation experienced by you in your daily work that led you to some kind of anguish, distress or suffering." 
The use of this technique was intended to encourage awareness about the theme and to facilitate the participants' access to unconscious content, as well as creating opportunities for them to express their subjectivities ${ }^{(14)}$.

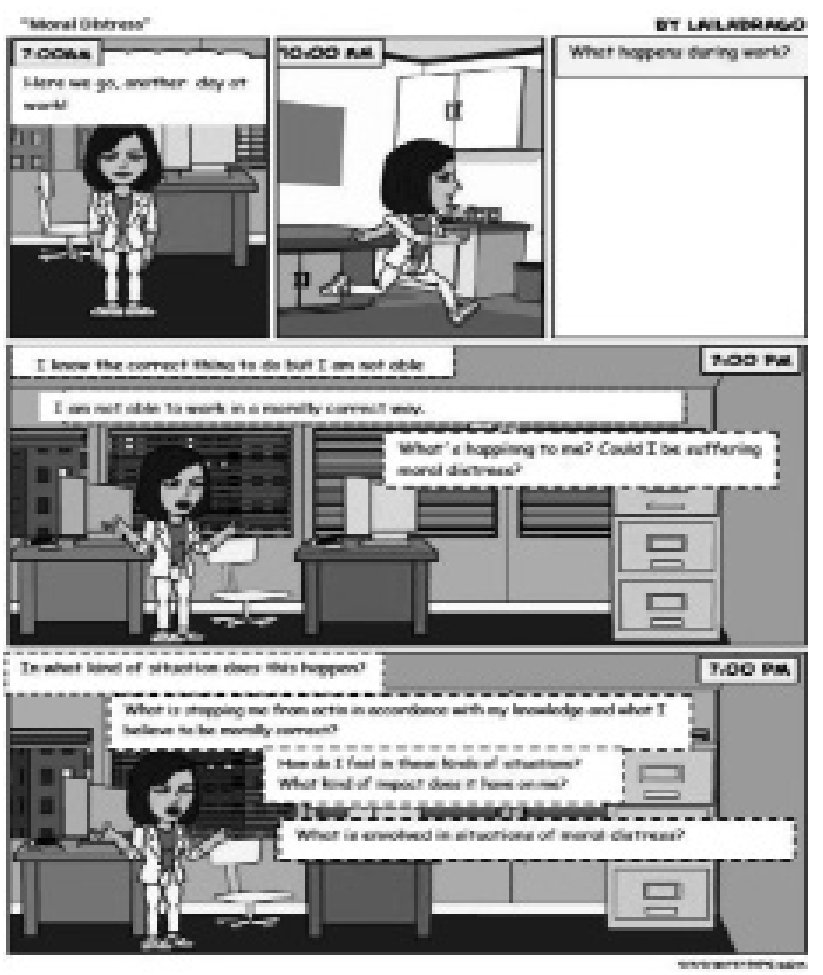

Figure 1 -Florianópolis, 2013.

The research participants were doctors, nurses, nursing technicians and community health workers (ACS's), totaling 28 professionals, of which three were doctors, four were nurses, three were nursing technicians and 18 were ACS's.

As an inclusion criterion, it was established that the professionals had to have worked in a municipal ESF for a minimum of one year. It was felt that this period of experience would allow professionals to establish closer and more meaningful relationships in the context of the ESF and also greater familiarity with the routines and standards of the services provided.

Laurence Bardin's content analysis technique, which "seeks to know what is addressed behind the words that are used", was used for the data analysis ${ }^{(15)}$. The categories emerged after the use of the central research question and the interpretation of Figure 1. The interviews were transcribed in full and analyzed according to the following phases: pre-analysis; exploration of the material; treatment of the results; and inference and interpretation ${ }^{(15)}$.

In the development of this study the authors followed the Brazilian rules and guidelines for human research as set out in Resolution CNS 466/2012. The study was approved by the Ethics Committee of the Federal University of Minas Gerais, as per report No. 749.142, and by the municipality that was the setting for this study, by letter of consent.

All the participants were informed about the objectives of the study and agreed to sign a consent form.
To ensure the anonymity of the participants it was decided to use codes in the presentation of the results, which were as follows: nurse (E); doctor (M), nursing technician (TE) and community health worker (ACS), followed by numbering according to the sequence of the interviews. For example: the first nurse interviewed (E1); the third doctor interviewed (M3).

\section{RESULTS}

To understand the experience of MD in the daily lives of professionals working within the Family Health Strate$\mathrm{gy}$, the authors identified the category "experiences of moral distress in health practices within the context of the $\mathrm{Fa}^{-}$ mily Health Strategy", based on the analysis of situations that were narrated through the use of the cartoon and the content of the interviews.

The interviews that were conducted made it possible to identify everyday situations encountered by members of the Family Health Team which compromised the quality of their work and which triggered symptoms of MD such as: difficulty in meeting demands that arise in the workplace; infrastructure-related issues (materials, Health Care Network and multidisciplinary team); and requirements imposed on individuals by the ESF.

\section{"EXPERIENCES OF MORAL DISTRESS IN HEALTH PRACTICES within the context of the Family Health Strategy"}

The experiences of MD identified by the participants of this study were related to the social vulnerabilities that service users of the health unit are exposed to and the weaknesses of the health system encountered by the ESF professionals. Thus, to highlight these experiences two sub-categories were established.

In the sub-category "social vulnerabilities as a phenomenon that generates moral distress" the participants revealed that they often encountered situations of family conflicts related to domestic violence and adverse socio-economic issues.
"So these things, violence, psychological aggression, we have a lot of these in the ESF, but I can't do anything! The patients have confidence in me; I think that if I remove this confidence that they have in me then the situation will worsen." [...] If something ha- ppens to me, I'll give you my sister's phone number, will you call her? [...] But I don't want you to make any official complaint [...]. "(ACS3)
"As my area deals with older patients I came across a case where a son assaulted his mother. Finally, I had to call to the social worker to go there because it was too much; I could no longer go there on my own." (ACS 4)
"A major difficulty is the socio-economic question, treatment. I know that a particular drug is the best, I know that a particular examination is the best, but I can't do it because the service is not available and the patient cannot afford to pay for it."(M2) which sometimes stops patients following a course of 
Social vulnerabilities and the absence of an inter-sectoral approach were cited as obstacles to decision-making.

"We know you there is legislation that guides what we do, but then we have to depend on other sectors that do not take appropriate action and we end up alone and have to resolve these situations. It often reaches a certain point where my knowledge is limited and then there are situations where we are stuck because we don't know how to reach a solution." (E3)

"We know that we have to solve problems but sometimes we are prevented by the patients themselves. What can health workers do? We have to respect the patient because otherwise they won't let us visit their home again. So there are times when we don't do anything and that is difficult because you are aware of the situation but can't do anything about it." (ACS 3)

The sub-category "weaknesses of the health system and their relationship to experiences of moral distress" revealed experiences of MD by FHS professionals in connection with weaknesses in the health system.

"I had a patient who was four months old and she had respiratory failure. She was wheezing, wheezing and the mother came and I didn't have a micro-nebulizer to use. So we sent her to the hospital and the hospital doctor took her and said, "she's just groaning because she is a little bit tired, she just has a little pain in her body "[...]" And this was a little girl with respiratory problems!! There was nothing more that could be done there, you know? There was no other remedy, no inhaler [...] there was no pediatrician there either, which was a service that we had. We were only able to use the official car to take her to the hospital; the mother would have had to make her own way back. She preferred not to go because she said "M3 how can I go there, how will I be able to get back?" (M2)

"The biggest problems are those that are inherent wi-
thin the Unified Health System (SUS), which is usu-
ally the major limiting factor because of the scarcity
of resources and delay in conducting tests, performing
operations etc. So this ends up distressing patients
and delaying diagnoses by professionals." (M1)

"Sometimes there is lack of some material, such as disinfectant, and you end up acting inappropriately so as not to stop the service."(E2)

"We see some cases that are not really for us. They are referred to us from elsewhere but we can't do the same thing... We often find another difficulty as well, patients come back to us from where they started out, from their starting point, which is the basic health service." (TE2)

Negative feelings, of helplessness and frustration, which were also associated with feelings of guilt, were also widely cited by the health professionals.
"[...] I know what's best, I know it would be easier for the patient as well, but I can't do anything." (M2)

"When we are trying to provide something that you know you is needed, that the person is in need of it right then, and that it's not feasible, that really makes you anxious." (E3)

"It gives you a sense of powerlessness, right? I can't do anything, my hands are tied."(M2)

\section{DISCUSSION}

Health care in Brazil has provided health care workers with experiences that they have never encountered before in hospitals and outpatient services. Within the ESF, professionals and service users are active individuals who share communal spaces and subjectivities. In intersubjective relationships, links are established that outline new contours to interpersonal relationships.

In this regard, health care meetings are permeated by the subjectivity of individuals, their vulnerabilities and their methods of coping ${ }^{(16)}$.

In this study, the participants brought with them their care experiences, which were shaped by the social vulnerabilities that service users were exposed to. Based on the content of the interviews, the authors inferred that the ACS's were most exposed to this because most of them lived in the community where they worked. Consequently they were not only workers, but also neighbors of the service users that that visited on a monthly basis.

ACS's are perceived by the population and Family Health Teams as individuals who are essential to the consolidation of the reorganization of the SUS. ACS's belong to a community, in which they become a reference point, as well as being active professionals whose role is to motivate the population in terms of social action and health care ${ }^{(17)}$.

Thus, such rapport represents a connotation that is related to the representation that FHS professionals have in relation to individuals and activities related to health care. In this sense, a study of the Humanization Policy in PHC in Brazil ${ }^{(18)}$ highlighted the work of interdisciplinary teams as an important tool for building relationships of trust and friendship based on rapport, which is bringing professionals closer to the reality experienced by service users.

However, this approach can contribute to the emergence of contradictions which are related to beliefs, values, ideals and ways of life, which conforms to the peculiarities of the ethical issues that occur in PHC ${ }^{(19)}$.

As a part of their everyday practices Family Health Teams experience extreme situations, such as poverty, social inequality, violence, neglect and disease, which favor the emergence of feelings of frustration, helplessness and distress, which were reported by the participants in this study.

A study conducted in southern Brazil (20) about incidences of MD experienced by health professionals found that this phenomenon is closely related to the following: 
proximity with the community and knowledge about problems and situations related to social vulnerability; failure to set limits in relation to service users; proximity to families; and intimate knowledge about families and their "careless" health practices. All these findings were echoed in the present study.

It is worth stressing once again that MD can be understood as a situation in which a professional recognizes their moral responsibility in the face of difficult situations and considers that there is a correct way to act, but due to institutional impediments or constraints they feel unable to make a correct decision; they consider their moral participation in the situation to be inadequate and may be affected by physical symptoms such as pain or distress that affects the body or the mind ${ }^{(9-10)}$.

A study of domestic violence against women ${ }^{(21)}$ showed that ACS's have the greatest proximity and rapport with service users and because of that they experience the problems and vicissitudes of their clients to a high degree. The aforementioned study prescribes the need for training for ACS's and other professionals regarding gender issues, which relate to violence against women, thereby empowering the guidelines of the SUS on this issue.

Regarding narratives that express weaknesses in the health system, it is clear that problems connected with the organization of work involving structural issues in relation to the ESF, such as the lack of apparatus for urgent and emergency care; the lack of support from other sectors to discuss and solve identified problems; and the shortage of equipment, medicines and transport hinder the quality of service and have ethical implications, both for professionals and for health service users: they also become a preeminent source of $\mathrm{MD}^{(9-10)}$.

The meta-synthesis developed in PHC ${ }^{(18)}$ is consistent with the present study and it has highlighted the lack of equipment and material resources in health units as having a negative impact on continuity of care, as well as generating unfavorable working conditions. Furthermore, it has identified the lack of an efficient health care network as being a barrier to humanized care.

The participants in the present study revealed, both through their interviews and their narratives in relation to the concept of MD, the reality of a challenging professional practice, in which expressing care in its most sublime form seems be paradoxical when the essence of actions designed to alleviate the suffering of others are hampered by anguish on the part of professionals, which is intrinsic to the work of health teams ${ }^{(10)}$. From this perspective, a move towards reversing the silent experience of MD would reveal the problems and the ethical challenges that $\mathrm{PHC}$ professionals are exposed to.

Integrating Family Health Teams entails being responsible for the population of a defined area and monitoring that population over time, which implies challenges to professional ethical practices. Family Health Teams perform functions that go beyond the traditional response to health needs and they develop continuous, specific and natural actions based on the establishment of rapport, respect and co-responsibility with the local population, all of which epitomize comprehensive health care.

Therefore, when professionals perceive difficulties in dealing with situations that compromise an ethical approach in the workplace this opens up the possibility of $\mathrm{MD}$, which is manifested by an inconsistency between professional actions and personal convictions, resulting in psychological imbalances characterized by feelings of suffering. In this scenario, professionals who experience situations of $\mathrm{MD}$ and who feel helpless in the face of emerging problems can choose to change the location where they work as a strategy to preserve their values in a new work context $^{(8)}$.

The creation of spaces in which situations that provoke MD can be described and discussed is essential in health care centers. The involvement of coordination and leadership, especially with regard to issues related to human and material resources, can ensure a healthy and productive work environment ${ }^{(10)}$.

The experience of studying real stories about the experience of ethical issues in daily working situations, and their implications for the individuals involved, made it possible to reflect on this topic, which is still little discussed in terms of health practices and actions. The reports of weaknesses in the health system showed that the professionals who participated in this study faced daily situations that contradicted their ethical precepts, which allowed for the greater possibility of the development of MD.

However, given the complexity of the issue under discussion, this study steered clear of generalization, since the authors addressed the participants in order to know how they experienced MD. Consequently, further studies should be conducted from an interdisciplinary perspective so that other silent phenomena, which result in MD, can be revealed.

\section{CONCLUSION}

The results of this research show that the Family Health Service workers who participated in this study experienced moral distress in their daily work. Social vulnerabilities, such as domestic violence and poor socio-economic conditions, in addition to the organizational weaknesses of the health system were the main triggers of this moral distress.

Such situations are not consistent with the principles of the Unified Health System (SUS) and they denote an assault on individual and collective rights, as well as human dignity. Such situations therefore have implications for health service professionals who, in this study, expressed feelings of helplessness and even guilt for failing to provide comprehensive assistance to service users.

The results indicate the desirability of promoting ethical care practices and management in health services in order to minimize moral distress. 


\section{RESUMO}

Objetivo: Compreender as vivências de Sofrimento Moral expressas no cotidiano da Estratégia de Saúde da Família.

Método: Trata-se de um estudo de caso com abordagem qualitativa, realizado entre os meses de agosto a outubro de 2014, cujo cenário foi um município de Minas Gerais. Participaram 28 profissionais das equipes de saúde da família. Os dados foram coletados por meio de entrevistas com roteiro semiestruturado, observação, técnica projetiva e, submetidos à análise de conteúdo temática.

Resultados: Os resultados apontaram que as questões rotineiras do serviço de saúde levam os profissionais a vivenciarem uma prática desafiadora ao lidarem diariamente com situações que contradizem seus preceitos éticos capazes de comprometer a qualidade do trabalho tornando-se disparadores de Sofrimento Moral.

Conclusão: As vulnerabilidades sociais, como violência doméstica e condições socioeconômicas precárias, além das fragilidades organizacionais do Sistema de Saúde, foram os principais geradores de Sofrimento Moral. Assim, considera-se necessária a reflexão ampliada sobre a temática por parte dos trabalhadores da Estratégia de Saúde da Família, com intuito de propiciar a minimização de vivências de sofrimento e uma prática profissional em consonância com seus valores éticos.

\section{DESCRITORES}

Estratégia de Saúde da Família; Ética; Dano Moral.

\section{RESUMEN}

Objetivo: La comprensión de las experiencias de Sufrimiento Moral expresadas en la vida cotidiana de la Estrategia Salud de la Familia.

Método: Es un estudio de caso con un enfoque cualitativo, realizado entre agosto y octubre de 2014, cuyo escenario fue un municipio de Minas Gerais. Con la asistencia de 28 profesionales de los equipos de salud de la familia. Los datos fueron recolectados a través de entrevistas con, la observación, la técnica semiestructurada proyectiva y sometidos a análisis de contenido temático.

Resultados: Los resultados mostraron que los problemas de servicio de salud de rutina conducen los profesionales experimentar una práctica difícil en el trato diario con situaciones que contradicen sus preceptos éticos que pueden comprometer la calidad del trabajo por lo que es desencadena el sufrimiento moral.

Conclusión: Las vulnerabilidades sociales como la violencia doméstica y las malas condiciones socioeconómicas a través de los puntos débiles de la organización del sistema de salud fueron los principales generadores de sufrimiento moral. Por lo tanto, considera que es necesario ampliar la reflexión sobre el tema de los trabajadores del Estrategia Salud de la Familia, con el objetivo de fomentar la minimización de sufrir experiencias y la práctica profesional en consonancia con sus valores éticos.

\section{DESCRIPTORES}

Estrategia Salud de la Familia; Ética; Daño Moral.

\section{REFERENCES}

1. Lavras C. Atenção Primária à Saúde e a organização de redes regionais de atenção à saúde no Brasil. Saúde soc. 2011;20 (4):867-874.

2. Oliveira, MAC, Pereira IC. Atributos essenciais da Atenção Primária e a Estratégia Saúde da Família. Rev. bras. enferm. 2013 Sept.;66(n.spe):158-64.

3. Lima EFA, Sousa AI, Primo CC, Leite FMC, Lima RCD, Maciel ELN. An assessment of primary care attributes from the perspective of female healthcare users. Rev. Latino-Am. Enfermagem. 2015 June; 23(3):553-559.

4. Mendes EV. As redes de atenção à saúde. Ciênc. saúde coletiva. 2010 Aug; 15(5): 2297-2305.

5. Junges JR, Zobolli ELCP, Patussi MP, Schaefer R, Nora CRD. Construção e validação do instrumento "Inventário de problemas éticos na atenção primária em saúde". Revista Bioética. 2014;22(2):309-17.

6. Dalmolin GL, Lunardi VL, Lunardi Filho WD. O sofrimento moral dos profissionais de enfermagem no exercício da profissão. Rev. Enferm. UERJ, 2009 Jan/Mar.;17(1):35-60.

7. Huffman DM, Rittenmeyer L. How professional nurses working in hospital environments experience moral distress: a systematic review. Crit Care Nurs Clin North Am. Knirsch CA, Jain NL, Pablos-Mendez A, Friedman C, Hripcsak. 2012;24(1):91-100.

8. Gomes D, Ramos FRS. Ética e comprometimento do profissional da saúde pós-reestruturação produtiva numa região metropolitana do sul do Brasil. Interface (Botucatu), Botucatu. 2014 Jun; 18(49):289-300.

9. Barlem E, Lunardi V, Tomaschewski J, Lunardi G, Lunardi Filho W, Schwonke C. Moral distress: challenges for an autonomous nursing professional practice. Revista da Escola de Enfermagem da USP. 2013;47(2):506-510.

10. Lunardi VL, Barlem ELD, Bulhosa MS, Santos SSC, Lunardi Filho WD, Silveira RS, Bao ACP, Dalmolin GL. Sofrimento Moral e a dimensão ética do trabalho da enfermagem. Rev. Brasileira Enfermagem. Jul-Ago/2009;62(4):599-603.

11. Dalmolin GL, Lunardi VL, Lunardi, GL, Barlem, ED, Silveira RS. Sufrimiento moral y síndrome de burnout: ¿Están relacionados esos dos fenómenos en los trabajadores de enfermería? Revista Latino-Am. Enfermagem. 2014;22(1):35-42.

12. Minayo MCS. O desafio do conhecimento: pesquisa qualitativa em saúde. 13ª ed. São Paulo: Hucitec; 2013.

13. Yin RK. Estudo de caso: planejamento e métodos. $5^{a}$ ed. Porto Alegre: Bookman; 2015.

14. Maffezzolli FEC, Ribeiro CM, Lima TMVV, Semprebom E, Prado, PHM, Mady EB. Reflexões sobre o Uso de Técnicas Projetivas na Condução de Pesquisas Qualitativas em Marketing. PMKT - Revista Brasileira de Pesquisa de Marketing, Opinião e Mídia. 2009;3:37-48.

15. Bardin L. Análise de conteúdo. Edição Revista e Atualizada. Lisboa: Edições 70; 2009.

16. Pinto, AGA, Jorge MSB. Prática clinica na estratégia saúde da família: relações entre equipes e usuários no território urbano. Revista Eletrônica Gestão \& Saúde. 2015;6(2):1514-29. 
17. Baralhas M, Pereira MAO. Prática diária dos agentes comunitários de saúde: dificuldades e limitações da assistência. Rev. bras. enferm. 2013 Junho, 66(3):358-365.

18. Nora CRD, Junges JR. Humanization policy in primary health care: a systematic review. Rev. Saúde Pública [online]. 2013 Dec;47(6):1186-1200

19. Lima AC, Morales, DA, Zoboli ELCP, Sartório NA. Problemas éticos na Atenção Básica: A visão de enfermeiros e médicos. Rev. Cogitare Enferm. 2009 Set,14(2):294-303

20. Briese G, Lunardi VL, Azambuja EP, Kerber NPC. O Sofrimento Moral dos Agentes Comunitários de Saúde. Cienc Cuid Saude 2015 Abr/Jun;14(2):1035-1042

21. Fonseca RMGS, Leal AERB, Skubs T, Guedes RN, Egry EY. Domestic violence against women from the perspective of the community health agent. Rev Latino-am Enfermagem 2009 Nov/Dez;17(6):974-80. 